\title{
Effects of Uniconazole on Growth and Cadmium Accumulation of Accumulator Plant Stellaria media
}

\author{
Keng Wen ${ }^{1, a}$, Lijin Lin ${ }^{2, b}$, Lei Liü,c, Wei Jiang ${ }^{4, d}$ and Ming'an Liao ${ }^{1, e^{*}}$ \\ ${ }^{1}$ College of Horticulture, Sichuan Agricultural University, Chengdu, Sichuan, China \\ ${ }^{2}$ Institute of Pomology and Olericulture, Sichuan Agricultural University, Chengdu, Sichuan, China \\ ${ }^{3}$ Chengdu Academy of Agriculture and Forestry Sciences, Chengdu, Sichuan, China \\ ${ }^{4}$ College of Chemistry and Life Science, Chengdu Normal University, Chengdu, Sichuan, China \\ a529112874@qq.com, bllj800924@163.com, 20925133@qq.com, d1399945180@qq.com, \\ Iman@sicau.edu.cn
}

${ }^{*}$ Corresponding author. Keng Wen, Lijin Lin and Lei Liu contributed equally to this work.

Keywords: Uniconazole; Stellaria media; Cadmium; Phytoremediation

Abstract: A pot experiment was carried out to investigate the effects of applying uniconazole on growth and cadmium $(\mathrm{Cd})$ accumulation of accumulator plant Stellaria media. The results showed that application of uniconazole inhibited the growth of $S$. media, and promoted the absorption and transport of $\mathrm{Cd}$ from soil. The biomass and soluble sugar content of $S$. media decreased with the increase of the concentration of uniconazole, whereas the activities of SOD, POD and CAT, the contents of photosynthetic pigments and soluble protein improved. With the increase of concentration of uniconazole, the $\mathrm{Cd}$ content and $\mathrm{Cd}$ accumulation in the shoots of $S$. media increased first and then decreased, and reached the maximum up to $67.24 \mathrm{mg} / \mathrm{kg}$ and $190.42 \mu \mathrm{g} /$ plant respectively when the dose of uniconazole was $40 \mathrm{mg} / \mathrm{L}$, which increased by $39.10 \%$ and $10.47 \%$ compared with the control, respectively. Therefore, application of uniconazole could enhance phytoremediation ability of $S$. media at the dose of $20-40 \mathrm{mg} / \mathrm{L}$.

\section{Introduction}

Uniconazole (S-3307) is a triazole derivative, which can promote plant photosynthesis, enhance absorption capacity of roots, protect plants from various environmental stresses, and has a broad-spectrum fungitoxic activity [1-2]. The biological activity of uniconazole is higher than that of paclobutrazol, and uniconazole is lower cost, lower toxicity, less pollution and specific capability to help to confer resistance in plants to low temperature stress as compared with paclobutrazol, making it as an ideal candidate for assisting remediation of heavy metal contaminated soil, especially in winter [3-6]. However, there are very few studies on cadmium (Cd) phytoremediation by application of uniconazole [7-9]. Stellaria media is a widely distributed annual herb of Caryophyllaceae, and also a Cd-accumulator plant [10]. In this study, we used the different concentrations of uniconazole to treat $S$. media, and studied the effects of uniconazole on growth and Cd accumulation of S. media. The aim of the study was to screen the best uniconazole concentration which could enhance the phytoremediation ability of $S$. media, and provided a reference for applying the plant hormones on other hyperaccumulators or accumulators for improving phytoremediation ability.

\section{Materials and Methods}

Materials. The soil samples used in the experiment were inceptisol soil, which were collected from the Ya' an campus farm of Sichuan Agricultural University (29 $\left.59^{\prime} \mathrm{N}, 102^{\circ} 59^{\prime} \mathrm{E}\right)$ in August 2014. The $S$. media seedlings with height of $10 \mathrm{~cm}$ were collected from the Ya'an campus farm in October 2014.

Experimental Design. The soil samples were air-dried and passed through a 5-mm sieve. Four kilograms of the air-dried soil was weighed into each polyethylene pot (18 cm high, $21 \mathrm{~cm}$ in diameter). $\mathrm{Cd}$ was added to soils as $\mathrm{CdCl}_{2} \cdot 2.5 \mathrm{H}_{2} \mathrm{O}$ at $25 \mathrm{mg} / \mathrm{kg}$ in August 2014, and the soil moisture was 
maintained at $80 \%$ of field capacity for 2 months. Four uniform $S$. media seedlings were transplanted into each pot in October 2014, and watered every day to keep the soil moisture content maintaining at $80 \%$ of field capacity. When $S$. media seedlings grow one month in Cd-contaminated soil, 5 concentrations $(0,10,20,40$ and $80 \mathrm{mg} / \mathrm{L})$ of uniconazole with 3 replicates were sprayed on the leaves of plants for each pot, respectively. The amount of each pot was $25 \mathrm{ml}$ of uniconazole solution. After uniconazole treatment one month, the upper mature leaves of $S$. media were collected to determine the photosynthetic pigment (chlorophyll a, chlorophyll b, total chlorophyll and carotenoid) contents [11]. The upper young shoots ( $2 \mathrm{~cm}$ in length) were collected to determine the superoxide dismutase (SOD) activity, peroxidase (POD) activity, catalase (CAT) activity and soluble protein content [11]. Then, the whole plants were then gently removed from the soil. The treatments of plants are described in the reference of Lin et al. (2014) [12]. The Cd concentrations in roots, stems and leaves were determined using an iCAP 6300 ICP spectrometer (Thermo Scientific, Waltham, MA, USA) [13]. The soluble sugar contents in shoots of $S$. media were determined by anthrone colorimetry with dry weight plant samples [11].

Experimental Design. Statistical analyses were conducted using SPSS 13.0 statistical software (IBM, Chicago, IL, USA). Data were analyzed by one-way analysis of variance with least significant difference (LSD) at the $\mathrm{p}=0.05$ confidence level.

\section{Results and Discussion}

Biomass. Compared with the control, spraying uniconazole decreased the root and shoot biomass of $S$. media with the increase of uniconazole concentration (Table 1). When the dose of uniconazole was 10, 20,40 and $80 \mathrm{mg} / \mathrm{L}$, the root biomass decreased by $1.68 \%(P>0.05), 2.29 \%(P>0.05), 8.87 \%(P<$ $0.05)$ and $14.83 \%(P<0.05)$ respectively compared with the control, and the shoot biomass decreased by $8.95 \%(P<0.05), 11.83 \%(P<0.05), 20.58 \%(P<0.05)$ and $24.09 \%(P<0.05)$ respectively. With the increase of uniconazole concentration, the root/shoot ratio of $S$. media increased at first and then reduced (Table 1).

Table 1 Biomass of $S$. media

\begin{tabular}{|c|c|c|c|c|}
\hline $\begin{array}{c}\text { Treatments } \\
(\mathrm{mg} / \mathrm{L})\end{array}$ & $\begin{array}{c}\text { Root biomass } \\
(\mathrm{g} / \text { plant })\end{array}$ & $\begin{array}{c}\text { Shoot biomass } \\
(\mathrm{g} / \text { plant })\end{array}$ & $\begin{array}{c}\text { Total biomass } \\
(\mathrm{g} / \text { plant })\end{array}$ & Root/shoot ratio \\
\hline 0 & $0.654 \pm 0.011 \mathrm{a}$ & $3.566 \pm 0.093 \mathrm{a}$ & $4.220 \pm 0.105 \mathrm{a}$ & 0.183 \\
\hline 10 & $0.643 \pm 0.014 \mathrm{a}$ & $3.247 \pm 0.066 \mathrm{~b}$ & $3.890 \pm 0.081 \mathrm{~b}$ & 0.198 \\
\hline 20 & $0.639 \pm 0.010 \mathrm{a}$ & $3.144 \pm 0.062 \mathrm{~b}$ & $3.783 \pm 0.072 \mathrm{~b}$ & 0.203 \\
\hline 40 & $0.596 \pm 0.008 \mathrm{~b}$ & $2.832 \pm 0.045 \mathrm{c}$ & $3.428 \pm 0.054 \mathrm{c}$ & 0.210 \\
\hline 80 & $0.557 \pm 0.013 \mathrm{c}$ & $2.707 \pm 0.151 \mathrm{c}$ & $3.264 \pm 0.164 \mathrm{c}$ & 0.206 \\
\hline
\end{tabular}

Photosynthetic pigment content. The chlorophyll a, chlorophyll $b$, total chlorophyll and carotenoid contents of the $S$. media increased first and then decreased with the increase of the concentration of uniconazole (Table 2). The contents of chlorophyll a, chlorophyll b, total chlorophyll and carotenoid reached the maxmium when the dose of uniconazole was $40 \mathrm{mg} / \mathrm{L}$. When the dose of uniconazole was $10,20,40$ and $80 \mathrm{mg} / \mathrm{L}$, the total chlorophyll content increased by $2.12 \%(P>0.05)$, $2.59 \%(P>0.05), 5.58 \%(P<0.05)$ and $4.58 \%(P>0.05)$ respectively compared with the control, and the content of carotenoid increased by $0.71 \%(P>0.05), 1.42 \%(P>0.05), 7.47 \%(P<0.05)$ and $6.05 \%(P>0.05)$ respectively. The chlorophyll a/b of $S$. media had a tendency to increase first and then decline with the increase of concentration of uniconazole, which reached the maximum value at 2.917 when the dose of uniconazole was $10 \mathrm{mg} / \mathrm{L}$ (Table 2).

Contents of carbon-nitrogen metabolites and antioxidant enzyme activity. The application of uniconazole increased soluble protein content, but drcreased the soluble sugar content of $S$. media (Table 3). Uniconazole improved the activities of SOD, POD and CAT (Table 3). When the dose of uniconazole was $40 \mathrm{mg} / \mathrm{L}$, SOD, POD and CAT activities got the maxma, respectively. When the dose of uniconazole was $10,20,40$ and $80 \mathrm{mg} / \mathrm{L}$, the activity of SOD increased by $1.59 \%(P>0.05), 4.49 \%$ 
$(P>0.05), 71.25 \%(P<0.05)$ and $19.05 \%(P<0.05)$ respectively compared with the control, the activity of POD increased by $6.28 \%(P>0.05), 11.27 \%(P>0.05), 46.65 \%(P<0.05)$ and $29.43 \%(P$ $<0.05)$ respectively, and the activity of CAT increased by $8.27 \%(P>0.05), 8.79 \%(P>0.05)$, $60.42 \%(P<0.05)$ and $43.79 \%(P<0.05)$ respectively.

Table 2 Photosynthetic pigment content of $S$. media

\begin{tabular}{|c|c|c|c|c|c|}
\hline $\begin{array}{c}\text { Treatments } \\
(\mathrm{mg} / \mathrm{L})\end{array}$ & $\begin{array}{c}\text { Chlorophyll a } \\
(\mathrm{mg} / \mathrm{g})\end{array}$ & $\begin{array}{c}\text { Chlorophyll b } \\
(\mathrm{mg} / \mathrm{g})\end{array}$ & $\begin{array}{c}\text { Total chlorophyll } \\
(\mathrm{mg} / \mathrm{g})\end{array}$ & $\begin{array}{c}\text { Chlorophyll } \\
\mathrm{a} / \mathrm{b}\end{array}$ & $\begin{array}{c}\text { Carotenoid } \\
(\mathrm{mg} / \mathrm{g})\end{array}$ \\
\hline 0 & $1.264 \pm 0.035 \mathrm{~b}$ & $0.438 \pm 0.017 \mathrm{~b}$ & $1.702 \pm 0.051 \mathrm{~b}$ & 2.886 & $0.281 \pm 0.009 \mathrm{~b}$ \\
\hline 10 & $1.294 \pm 0.036 \mathrm{ab}$ & $0.444 \pm 0.016 \mathrm{ab}$ & $1.738 \pm 0.052 \mathrm{ab}$ & 2.917 & $0.283 \pm 0.014 \mathrm{~b}$ \\
\hline 20 & $1.297 \pm 0.040 \mathrm{ab}$ & $0.449 \pm 0.019 \mathrm{ab}$ & $1.746 \pm 0.059 \mathrm{ab}$ & 2.886 & $0.285 \pm 0.010 \mathrm{ab}$ \\
\hline 40 & $1.327 \pm 0.011 \mathrm{a}$ & $0.470 \pm 0.015 \mathrm{a}$ & $1.797 \pm 0.026 \mathrm{a}$ & 2.825 & $0.302 \pm 0.010 \mathrm{a}$ \\
\hline 80 & $1.313 \pm 0.014 \mathrm{ab}$ & $0.466 \pm 0.006 \mathrm{ab}$ & $1.780 \pm 0.010 \mathrm{ab}$ & 2.816 & $0.298 \pm 0.004 \mathrm{ab}$ \\
\hline
\end{tabular}

Table 3 Contents of carbon-nitrogen metabolites and antioxidant enzyme activities of $S$. media

\begin{tabular}{|c|c|c|c|c|c|}
\hline $\begin{array}{c}\text { Treatments } \\
(\mathrm{mg} / \mathrm{L})\end{array}$ & $\begin{array}{c}\text { Soluble protein } \\
\text { content }(\mathrm{mg} / \mathrm{g})\end{array}$ & $\begin{array}{c}\text { Soluble sugar } \\
\text { content }(\%)\end{array}$ & $\begin{array}{c}\text { SOD activity } \\
(\mathrm{U} / \mathrm{g})\end{array}$ & $\begin{array}{c}\text { POD activity } \\
(\mathrm{U} / \mathrm{g})\end{array}$ & $\begin{array}{c}\text { CAT activity } \\
{[\mathrm{mg} /(\mathrm{g} \cdot \mathrm{min})]}\end{array}$ \\
\hline 0 & $15.63 \pm 0.91 \mathrm{c}$ & $9.78 \pm 0.54 \mathrm{a}$ & $107.86 \pm 1.94 \mathrm{c}$ & $909.21 \pm 3.75 \mathrm{c}$ & $16.15 \pm 0.54 \mathrm{c}$ \\
\hline 10 & $16.18 \pm 0.88 \mathrm{c}$ & $8.86 \pm 0.16 \mathrm{ab}$ & $109.57 \pm 3.37 \mathrm{c}$ & $966.34 \pm 84.01 \mathrm{c}$ & $17.49 \pm 0.56 \mathrm{c}$ \\
\hline 20 & $20.12 \pm 0.17 \mathrm{~b}$ & $8.495 \pm 0.36 \mathrm{bc}$ & $112.70 \pm 1.62 \mathrm{c}$ & $1011.69 \pm 85.98 \mathrm{bc}$ & $17.58 \pm 0.48 \mathrm{c}$ \\
\hline 40 & $26.40 \pm 1.41 \mathrm{a}$ & $7.79 \pm 0.18 \mathrm{c}$ & $184.70 \pm 4.73 \mathrm{a}$ & $1333.33 \pm 59.73 \mathrm{a}$ & $25.92 \pm 0.73 \mathrm{a}$ \\
\hline 80 & $22.36 \pm 1.13 \mathrm{~b}$ & $8.01 \pm 0.44 \mathrm{bc}$ & $128.41 \pm 1.19 \mathrm{~b}$ & $1176.83 \pm 54.61 \mathrm{ab}$ & $23.23 \pm 0.71 \mathrm{~b}$ \\
\hline
\end{tabular}

Cd Accumulation. With the increase of the concentration of uniconazole, the contents of $\mathrm{Cd}$ in roots of $S$. media decreased, while the Cd content in shoots of $S$. media increased first and then decreased (Table 4). The maximum of Cd content in shoots was at $40 \mathrm{mg} / \mathrm{L}$ uniconazole. When the dose of uniconazole was $10,20,40$ and $80 \mathrm{mg} / \mathrm{L}, \mathrm{Cd}$ content in the shoots increased by $6.87 \%(P>$ $0.05), 21.00 \%(P<0.05), 39.10 \%(P<0.05)$ and $30.58 \%(P<0.05)$ respectively compared with the control. Uniconazole decreased $\mathrm{Cd}$ amount in roots of $S$. media, and had the decreasing trend with the increase of the concentration of uniconazole (Table 4). However, when the dose of uniconazole was 20 and $40 \mathrm{mg} / \mathrm{L}, \mathrm{Cd}$ amount in shoots of $S$. media increased, which increased by $6.68 \%(P<0.05)$ and $10.47 \%(P<0.05)$ respectively compared with the control. When the dose of uniconazole was 10 and $80 \mathrm{mg} / \mathrm{L}, \mathrm{Cd}$ amount in shoots of $S$. media decreased. The same as the Cd amount in shoots, only 20 and $40 \mathrm{mg} / \mathrm{L}$ uniconazole increased $\mathrm{Cd}$ amount in whole plants of $S$. media, and 10 and $80 \mathrm{mg} / \mathrm{L}$ uniconazole decreased that.

Table 4 Cd accumulation of $S$. media

\begin{tabular}{|c|c|c|c|c|c|}
\hline $\begin{array}{c}\text { Treatments } \\
(\mathrm{mg} / \mathrm{L})\end{array}$ & $\begin{array}{c}\text { Cd content in } \\
\text { roots } \\
(\mathrm{mg} / \mathrm{kg})\end{array}$ & $\begin{array}{c}\text { Cd content in } \\
\text { shoots } \\
(\mathrm{mg} / \mathrm{kg})\end{array}$ & $\begin{array}{c}\text { Cd amount in } \\
\text { roots } \\
(\mu \mathrm{g} / \mathrm{plant})\end{array}$ & $\begin{array}{c}\text { Cd amount in } \\
\text { shoots } \\
(\mu \mathrm{g} / \mathrm{plant})\end{array}$ & $\begin{array}{c}\text { Cd amount in } \\
\text { whole plant } \\
(\mu \mathrm{g} / \mathrm{plant})\end{array}$ \\
\hline 0 & $139.88 \pm 4.07 \mathrm{a}$ & $48.34 \pm 1.90 \mathrm{c}$ & $91.48 \pm 1.08 \mathrm{a}$ & $172.38 \pm 2.25 \mathrm{~b}$ & $263.86 \pm 3.33 \mathrm{ab}$ \\
\hline 10 & $139.24 \pm 3.87 \mathrm{a}$ & $51.66 \pm 2.35 \mathrm{c}$ & $89.53 \pm 0.52 \mathrm{ab}$ & $167.74 \pm 4.19 \mathrm{~b}$ & $257.27 \pm 4.71 \mathrm{~b}$ \\
\hline 20 & $136.28 \pm 2.09 \mathrm{a}$ & $58.49 \pm 2.11 \mathrm{~b}$ & $87.08 \pm 0.01 \mathrm{~b}$ & $183.89 \pm 2.99 \mathrm{a}$ & $270.98 \pm 2.97 \mathrm{a}$ \\
\hline 40 & $134.27 \pm 6.04 \mathrm{a}$ & $67.24 \pm 1.75 \mathrm{a}$ & $80.02 \pm 2.46 \mathrm{c}$ & $190.42 \pm 1.92 \mathrm{a}$ & $270.45 \pm 4.38 \mathrm{a}$ \\
\hline 80 & $128.27 \pm 4.62 \mathrm{a}$ & $63.12 \pm 1.58 \mathrm{ab}$ & $71.45 \pm 0.94 \mathrm{~d}$ & $170.87 \pm 5.26 \mathrm{~b}$ & $242.31 \pm 4.32 \mathrm{c}$ \\
\hline
\end{tabular}

\section{Conclusions}

The application of uniconazole inhibited the growth of $S$. media, and promoted the absorption and transport of $\mathrm{Cd}$ from soil. The biomass and soluble sugar content of $S$. media decreased with the increase of the concentration of uniconazole, whereas the activities of SOD, POD and CAT, the contents of photosynthetic pigments and soluble protein improved. With the increase of concentration 
of uniconazole, the $\mathrm{Cd}$ content and $\mathrm{Cd}$ accumulation in the shoots of $S$. media increased first and then decreased, and reached the maximum up to $67.24 \mathrm{mg} / \mathrm{kg}$ and $190.42 \mu \mathrm{g} /$ plant respectively when the dose of uniconazole was $40 \mathrm{mg} / \mathrm{L}$, which increased by $39.10 \%$ and $10.47 \%$ compared with the control, respectively. Therefore, application of uniconazole could enhance phytoremediation ability of $S$. media at the dose of $20-40 \mathrm{mg} / \mathrm{L}$.

\section{Acknowledgements}

This work was financially supported by the 2016 Innovation Training Program of University Student (201610626032) and the Application Infrastructure Project of Science and Technology Department of Sichuan Province (2016JY0258).

\section{References}

[1] D. Wang, H. Yang, F. Zhang and D. Cao: Agricultural Research in the Arid Areas Vol. 34, (2016), p. 94.

[2] R.A. Fletcher and G. Hofstra: Journal of Plant Growth Regulation Vol. 9 (1990), p. 207.

[3] X. Liu and X. Liu: Acta Prataculturae Sinica Vol. 15 (2006), p. 48.

[4] B. Xie, Q. Wang, H. Zhang, A. Li, F. Hou, B. Wang, S. Dong and L. Zhang: Acta Agriculturae Boreali-Sinica Vol. 31 (2016), p. 155.

[5] X. Wang, M. Yu and L. Tao: Crops Vol. 2 (1993), p. 33.

[6] K. Izumi, I. Yamaguchi, A. Wada, H. Oshio and N. Takahashi: Plant \& Cell Physiology Vol. 25 (1984), p. 611.

[7] R.M. Thomas and V.P. Singh: Photosynthetica Vol. 32 (1996), p. 145.

[8] S. Purohit and V.P. Singh: Photosynthetica. Vol. 36 (2000), p. 597.

[9] V.P. Singh: Journal of Plant Growth Regulation Vol. 12 (1993), p. 1.

[10] L. Lin, B. Ning, M. Liao, H. Lan and H. Liang: Ecology and Environmental Sciences Vol. 23 (2014), p. 673.

[11] Z.B. Hao, J. Chang and Z. Xu: Plant Physiology Experiment (Harbin Institute of Technology Press, China 2004).

[12] L. Lin, M. Liao, L. Mei, J. Cheng, J. Liu, L. Luo and Y. Liu: Environmental Progress \& Sustainable Energy Vol. 33 (2014), p. 1251.

[13] A. Tessier, P.G.C. Campbell and M. Bisson: Analytical Chemistry Vol. 51 (1979), p. 844. 